\title{
Pengaruh Penambahan PVP Pada Indikator Alami Curcuma Longa L. Untuk Mendeteksi Boraks Pada Bakso
}

\section{Effect Of Addition Of Pvp To Natural Indicator Of Turmeric Curcuma Longa L. For Detecting Borax In Meatballs}

\author{
Neneng Bisyaroh \\ Program Studi Farmasi, Fakultas Ilmu Kesehatan, Universitas Ibrahimy \\ Email: bisyaroh.neneng@gmail.com
}

\begin{abstract}
ABSTRAK
Boraks banyak digunakan dalam pembuatan berbagai makanan seperti bakso, mie basah, pisang molen, lemper, siomay, lontong, ketupat, dan pangsit. Kurkumin yang dikandung oleh kunyit dapat mendeteksi adanya kandungan boraks pada bakso dengan menguraikan ikatan-ikatan boraks menjadi asam borat dan mengikatnya menjadi senyawa kompleks warna rosa yang disebut dengan senyawa boron cyano kurkumin kompleks. Pembuatan strip test dengan cara mengimobilisasikan kertas saring pada indikator kunyit yang telah ditambah polivinil pirolidon $1 \%$ dan diaplikasikan pada bakso sehingga dapat mengetahui ada tidaknya kandungan boraks dalam bakso tersebut. Waktu respon dari strip test yaitu 30 detik. Strip test dari ekstrak kunyit tanpa penambahan polivinil pirolidon meninggalkan sisa warna kunyit pada bakso sedangkan hasil strip test dari ekstrak kunyit dengan penambahan polivinil pirolidon $1 \%$ tidak meninggalkan sisa warna kunyit pada bakso. Ketiga sampel bakso yang diambil di wilayah Pondok Sukorejo tidak mengandung boraks.
\end{abstract}

Kata kunci : Kandungan Boraks dalam Bakso, Strip Test, Indikator Kunyit

\section{ABSTRACT}

Borax is widely used in making various foods such as meatballs, wet noodles, pisang molen, lemper, siomay, lontong, ketupat, and pangsit. Curcumin contained in turmeric can detect the presence of borax content in meatballs by breaking down the borax bonds to boric acid and binding them to rosa color complex compounds called boron compounds cyano curcumin complex. Making a test strip by immobilizing filter paper on the turmeric indicator which has been added polyvinyl pyrrolidone $1 \%$ and applied to the meatballs so that it can determine whether there is a borax content in the meatballs. The response time of the test strip is 30 seconds. The test strips of turmeric extract without the addition of polyvinyl pyrrolidone leave the remaining turmeric color in the meatballs while the test strip results of turmeric extract with the addition of polyvinyl pyrrolidone 1\% do not leave the remaining turmeric color in the meatballs. The three meatball samples taken in the Pondok Sukorejo area did not contain borax.

Keywords: Borax Content In Meatballs, Strip Test, Turmeric Indicator.

\section{PENDAHULUAN}

Pengunaan pengawet seperti

boraks pada makanan mempunyai dampak masing- masing terhadap produsen maupun konsumen. Dari sudut pandang produsen dengan menggunakan boraks pada produk makanan akan menghasilkan tekstur makanan yang lebih baik dan tahan lebih lama sehingga pada ujungnya akan memberikan keuntungan segi ekonomi terhadap pedagang. 
Sedangkan pengaruhnya terhadap konsumen membahayakan kesehatan baik jangka waktu panjang maupun jangka pendek. Boraks banyak digunakan dalam pembuatan berbagai makanan seperti bakso, mie basah, pisang molen, lemper, siomay, lontong, ketupat, dan pangsit.

Kunyit (Curcuma longa Linn.) termasuk salah satu tanaman rempah dan obat, habitat asli tanaman ini meliputi wilayah Asia khususnya Asia Tenggara. Kunyit merupakan salah satu indikator kimia alami yang mengandung senyawa kurkumin. Kunyit (Curcuma longa Linn.) termasuk salah satu tanaman rempah dan obat, habitat asli tanaman ini meliputi wilayah Asia khususnya Asia Tenggara. Kunyit merupakan salah satu indikator kimia alami yang mengandung senyawa kurkumin. Kurkumin yang dikandung oleh kunyit dapat mendeteksi adanya kandungan boraks pada bakso dengan menguraikan ikatan-ikatan boraks menjadi asam borat dan mengikatnya menjadi senyawa kompleks warna rosa yang disebut dengan senyawa boron cyano kurkumin kompleks.

Strip test yang digunakan untuk mendeteksi boraks pada bakso yaitu terdiri dari indikator kunyit dan polivinil pirolidon. Pembuatan strip test dengan cara mengimobilisasikan kertas saring pada indikator kunyit yang telah ditambah polivinil pirolidon $1 \%$ dan diaplikasikan pada bakso sehingga dapat mengetahui ada tidaknya kandungan boraks dalam bakso tersebut.

\section{METODE PENELITIAN}

Penelitian ini bersifat eksperimental laboratorik yang dilakukan di Laboratorium Kimia Dasar, Prodi Farmasi, Fakultas Ilmu Kesehatan, Universitas Ibrahimy pada Bulan Februari-Agustus 2019. Dalam penelitian ini tahapan yang dilakukan adalah pembuatan strip test, optimasi bahan pengikat, fabrikasi sensor, dan karakterisasi waktu respon strip test.

Alat-alat yang digunakan adalah timbangan analitik OHAUS PA214, timbangan kue, gelas ukur $10 \mathrm{~mL}$, vial, blender, magnetic stirer, pisau, saringan, lemari pendingin.

Pembuatan strip test menggunakan 2 perlakuan, yaitu tanpa penambahan polivinil pirolidon dan penambahan polivinil pirolidon. Pembuatan indikator kunyit yaitu dengan menimbang kunyit sebanyak 30 
gram kemudian diparut dan diperas sehingga didapatkan $\pm 11 \mathrm{~mL}$ ekstrak. Pembuatan strip test dengan cara mengimobilisasikan kertas saring pada indikator kunyit yang telah ditambah polivinil pirolidon $1 \%$. Strip test dilihat waktu responnya saat diujikan pada bakso yang ada di wilayah Pondok Sukorejo dan dapat mengetahui ada tidaknya kandungan boraks dalam bakso tersebut.

\section{HASIL DAN PEMBAHASAN}

Waktu respon dari strip test baik dari ekstrak kunyit tanpa penambahan polivinil pirolidon dan dengan penambahan polivinil pirolidon yaitu 30 detik. Hasil strip test dari ekstrak kunyit tanpa penambahan polivinil pirolidon meninggalkan sisa warna kunyit pada bakso sedangkan hasil strip test dari ekstrak kunyit dengan penambahan polivinil pirolidon $1 \%$ tidak meninggalkan sisa warna kunyit pada bakso.

Peneliti menggunakan 3 sampel bakso yang ada di wilayah Pondok Sukorejo. Dari ketiga bakso hasilnya negatif yang ditandai warna pada strip test tetap kuning. Untuk membandingkan perubahan warna pada strip test saat diujikan pada bakso yang mengandung boraks dan tidak mengandung boraks, menggunakan larutan boraks $1 \%$. Hasil pengujian strip test pada bakso ditunjukkan pada gambar 1.

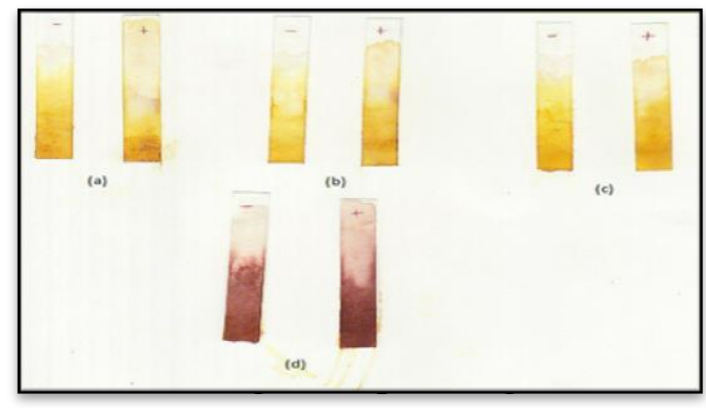

menunjukkan penempatan strip test saat pengujian pada bakso.

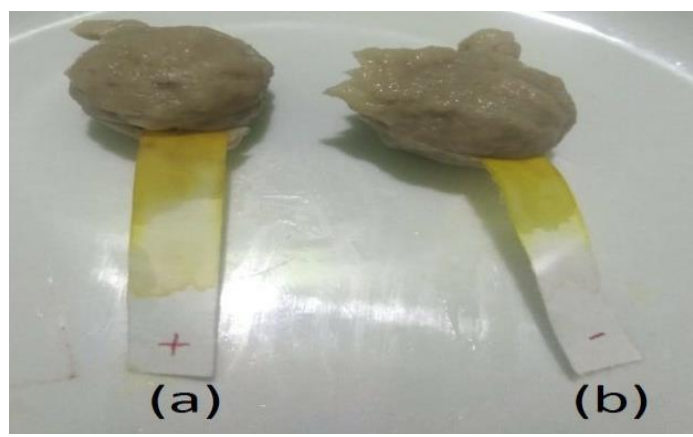

Gambar 2. Aplikasi strip test pada bakso (a) strip test dengan ekstrak kunyit dengan penambahan polivinil pirolidon dan (b) strip test dengan ekstrak kunyit tanpa penambahan polivinil pirolidon.

Pembuatan ekstrak kunyit yaitu dengan menimbang kunyit sebanyak 30 gram kemudian diparut dan diperas sehingga didapatkan $\pm 11 \mathrm{~mL}$ ekstrak kunyit. Kemudian ekstrak kunyit diberikan 2 perlakuan yaitu dengan penambahan bahan pengikat polivinil pirolidon dan tanpa penambahan bahan pengikat polivinil pirolidon. Pada 
ekstrak kunyit dengan perlakuan penambahan bahan pengikat, ditambahkan polivinil pirolidon sebanyak $1 \%$.

Waktu respon dapat dinyatakan sebagai waktu antara pertama kali sensor direaksikan dengan sampel dan waktu pertama kali respon sensor menghasilkan sinyal yang stabil (steady-state). Waktu respon dari strip test baik dari ekstrak kunyit tanpa penambahan polivinil pirolidon dan dengan penambahan polivinil pirolidon yaitu 30 detik. Penentuan waktu respon ini didasarkan pada perubahan warna yang terjadi pada strip test saat diujikan pada bakso.

Pada ekstrak kunyit tanpa penambahan polivinil pirolidon akan meninggalkan bekas warna pada bakso sedangkan pada ekstrak kunyit dengan penambahan polivinil pirolidon tidak meninggalkan bekas warna pada bakso. Hal ini dapat terjadi karena polivinil pirolidon mengikat zat warna ekstrak kunyit saat diimobilisasikan pada kertas saring, sehingga saat diaplikasikan pada bakso zat warna dari ekstrak kunyit tidak lepas.

Pada pengujian strip test pada bakso dapat dilihat pada gambar 1 . Gambar (a) menunjukkan perubahan warna pada strip test setelah diujikan pada sampel a. Gambar menunjukkan perubahan warna pada strip test setelah diujikan pada sampel b. Gambar (c) menunjukkan perubahan warna pada strip test setelah diujikan pada sampel c. Gambar (d) menunjukan warna pembanding untuk strip test bila diujikan pada bakso yang mengandung boraks dengan menggunakan larutan boraks $1 \%$. Pada gambar a-d terdapat tanda (-) yang menunjukkan strip test dengan ekstrak kunyit tanpa penambahan polivinil pirolidon sedangkan tanda (+) menunjukkan strip test dengan ekstrak kunyit dengan penambahan polivinil pirolidon. Dari ketiga gambar tersebut dapat disimpulkan bahwa ketiga sampel bakso tidak mengandung boraks baik pada strip test dengan ekstrak kunyit tanpa penambahan polivinil pirolidon dan strip test dengan ekstrak kunyit tanpa penambahan polivinil pirolidon.

\section{SIMPULAN DAN SARAN}

Waktu respon dari strip test baik dari ekstrak kunyit tanpa penambahan polivinil pirolidon dan dengan penambahan polivinil pirolidon yaitu 30 detik. Pada ekstrak kunyit tanpa penambahan polivinil pirolidon akan 
meninggalkan bekas warna pada bakso sedangkan pada ekstrak kunyit dengan penambahan polivinil pirolidon tidak meninggalkan bekas warna pada bakso. Ketiga sampel bakso yang dibeli di wilayah Pondok Sukorejo tidak mengandung boraks

Penelitian ini selanjutnya dapat dikembangkan menjadi strip test dari indikator kunyit menggunakan membran yang dapat dimakan (edible).

\section{DAFTAR PUSTAKA}

Effendi, D.H., Hardianti, S., Arumsari, A. 2017. Pembuatan Alat Uji Carik Selofan untuk Analisis Boraks dan Formalin. J Prosiding Farmasi. Vol 2 : 2460 6472.

Khamid, IR. 2006. Bahaya Boraks Bagi Kesehatan. Jakarta.
Penerbit Kompas.

Kusbiantoro, D., Y. Purwaningrum. 2018. Pemanfaatan kandungan metabolit sekunder pada tanaman kunyit dalam mendukung peningkatan pendapatan masyarakat Utilization of secondary metabolite in the turmeric plant to increase community income. 17(1), 544-549.

Kuswandi, B. 2010. Sensor Kimia: Teori, Praktek \& Aplikasi. Jember: UPT Penerbitan Universitas Jember.

Sugiyatmi, S. (2006). Analisis Faktorfaktor Risiko Pencemaran Bahan Toksik Boraks dan Pewarna Pada Makanan Jajanan Tradisional yang Dijual di Pasar-pasar Kota Semarang Tahun 2006. Semarang: Program Pasca Sarjana Universitas Diponegoro Semarang. 